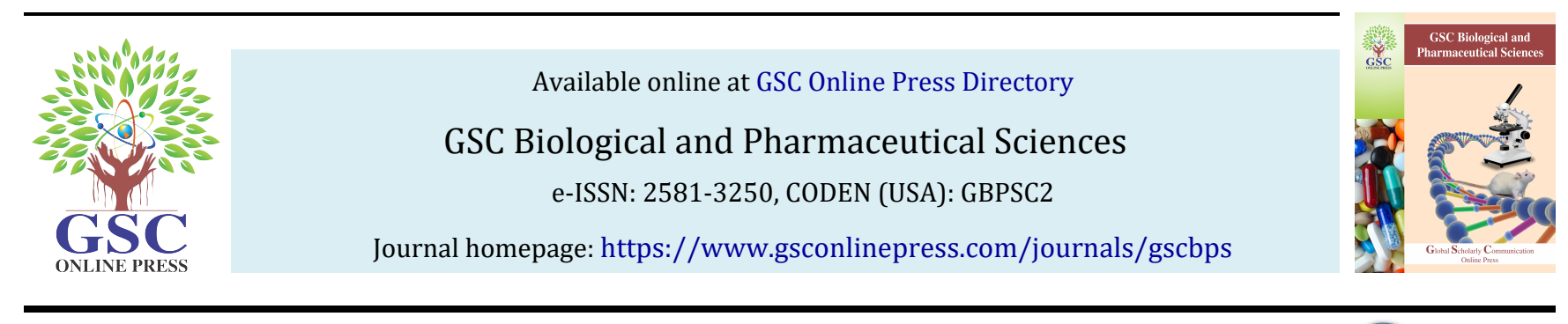

(RESEARCH ARTICLE)

\title{
Road side flora of Pazhavoor, Tirunelveli district, Tamil Nadu, South India
}

\author{
Kensa Mary V.*, Sangeetha M and Lekshmi J. L. \\ Department of Botany and Research Centre, S.T. Hindu College, Nagercoil -629 002, Tamil Nadu, India.
}

Publication history: Received on 17 June 2018; revised on 13 July 2018; accepted on 14 July 2018

Article DOI: https://doi.org/10.30574/gscbps.2018.4.1.0051

\begin{abstract}
Roadsides are habitats with very specific environmental conditions, often substantially differing from their natural surroundings. However, roads can have a positive effect on local vascular plant species richness. The vegetation of Pazhavoor were surveyed, the Road side flora of, a total of 103 species belongs to 87 genera and 34 families are recorded. Out of 34 families, 13 families belongs to Monocot (Liliaceae, Poaceae, Arecaceae, Ascelepiadaceae etc) and 90 families are Dicots (Malvaceae, Euphorbiaceae, Lamiceae, Meliaceae, Acanthaceae, etc). Fabaceae is the most dominant family with 12 species. Euphorbiaceae is the second largest families with 11 species followed by Malavaceae (10), Amaranthaceae (9), Poaceae (8), Acanthaceae (7), Asterceae (4), Solanaceae (3), Rubiaceae (2), Vitaceae (1). No endemic species has been found from the study area. The commonly occurring species are Abutilon indicum, Acalphaindica, Barleria sps, Cassia auriculata, Chlorsis barbata, Cocus nucifera, Euphorbia sps, Jatropha curcus, Mollugo nudicaulis, Tamarindus indica, Tribulus terrestris, Tridax prcumbens, Vernoniacinerea. The dominant tree species found are Azadirachta indica, Cocus nucifera, Ficus religiosa followed by Tectona grandis. Among the total 103 species, 12 are trees, 22 shrubs, 64 herbs and 5 climbers. More over 96 species are wild and 7 species are cultivated. Seeds is used to propagate 103 plant species, 2 species by seeds/stem cutting, 3 species were propagated using their bulbs, 2 species were propagated by stem cutting, Rest of the plants propagated using their different plant parts (bud, corm, Rhizome, seed, tubers). In this study environmental conditions and propagules maturity etc were found key factors for their regeneration. These results show that roadside vegetation can contribute to the conservation of the flora of study area.
\end{abstract}

Keywords: Climbers; Flora; Natural; Regeneration; Vegetation; Roadsides

\section{Introduction}

Roads are an integral part of daily life for most people in the world, providing mobility across our landscape. Road side vegetations are open to contaminations of diverse heavy metals and other gaseous pollutants, and to physical disturbances of being trampled by pedestrians and crushed by vehicles continuously. The roadside may be a refuge for more species, and the pattern of vegetation distribution is affected by road age and distance from the road verge [1]. The main reasons for the presence of different species along roads are often changes in physical and chemical properties of soil [2], light conditions [3], as well as microclimate [4]. Roads also influence the spread and growth of species by serving as corridors for movement as well as providing habitat for establishment of propagules. The objectives of this study are to evaluate the current status of species in the study area.

\footnotetext{
${ }^{*}$ Corresponding author

E-mail address: surejkensa@gmail.com
}

Copyright (C) 2018 Author(s) retain the copyright of this article. This article is published under the terms of the Creative Commons Attribution Liscense 4.0. 


\section{Material and methods}

The study area Pazhavoor which belongs to Radapuram taluk and Tirunelveli district. Most of people are doing agriculture. They are cultivating Jasminum and ground nuts. There are 2000 houses are available in the study area. Many numbers of ponds and canals are present in the study area. Some of the people are rearing cattles also. Many wind mills are constructed and used in the production of electricity. Here one Shiva temple is there which was constructed by the Pandiya king. Here two primary, one higher secondary schools, police stations, primary health centre and agricultural Co-operative centre are available.

The task of inventorying the plant diversity of Pazhavoor campus was undertaken systematically and intensively from September 2014 to September 2015, to cover most species in flowering and fruiting stages and also to cover various seasons. Field observations were made and plants were photographed. Plant species were identified using regional floras [5-8]. The collected materials were poisoned using standard herbarium techniques [9]. Well-preserved specimens with voucher numbers were deposited in the Herbarium of the P.G Department of Botany and Research, S.T. Hindu College, Nagercoil, Tamil Nadu, India.

\section{Results and discussion}

The vegetation of Pazhavoor were surveyed, the Road side flora of, a total of 103 species belongs to 87 genera and 34 families are recorded (Table 1). Out of 34 families, 13 families belong to Monocot (Liliaceae, Poaceae, Arecaceae, Ascelepiadaceae, etc) and 90 families are Dicots (Malvaceae, Euphorbiaceae, Lamiceae, Meliaceae, Acanthaceae, etc). Fabaceae is the most dominant family with 12 species (Table 1 and Figure 1).

Table 1 List of plant species recorded from the study area

\begin{tabular}{|c|c|c|c|c|c|}
\hline $\begin{array}{l}\text { Sr. } \\
\text { No }\end{array}$ & Name of the plants & Family & Habit & $\begin{array}{l}\text { Nature of } \\
\text { Plant }\end{array}$ & Cotyledons \\
\hline 1 & Abutilon indicum(Link) sweet & Malvaceae & Shrub & Wild & Dicot \\
\hline 2 & Acalypha fruticosa Forssk. & Euphorbiaceae & Shrub & Wild & Dicot \\
\hline 3 & Acalypha indica L. & Euphorbiaceae & Herb & Wild & Dicot \\
\hline 4 & Achyranthes aspera L. & Amaranthaceae & Herb & Wild & Dicot \\
\hline 5 & Aerva lanata (L.) Juss.ex.Schult. & Amaranthaceae & Herb & Wild & Dicto \\
\hline 6 & Aloe vera (L.) Burm. $f$. & Liliaceae & Herb & Cultivated & Monocot \\
\hline 7 & Alternanthera pungens Kunth. & Amaranthaceae & Herb & Wild & Dicot \\
\hline 8 & Alysicarpus vaginalis (L.) & Fabaceae & Herb & Wild & Dicot \\
\hline 9 & Amaranthus hybridus L. & Amaranthaceae & Herb & Wild & Dicot \\
\hline 10 & Andrographis echioides (L.) Nees & Acanthaceae & Herb & Wild & Dicot \\
\hline 11 & Anisomeles malabarica (L.) & Lamiceae & Herb & Cultivated & Dicot \\
\hline 12 & Apluda mutica $\mathrm{L}$. & Poaceae & Herb & Wild & Monocot \\
\hline 13 & Aristida purpurea Nutt. & Poaceae & Herb & Wild & Monocot \\
\hline 14 & Azadirachta indica A. Juss & Meliaceae & Tree & Cultivated & Dicot \\
\hline 15 & Barleria cristata L. & Acanthaceae & Shrub & Wild & Dicot \\
\hline 16 & Barleria lupulina Lindi & Acanthaceae & Shrub & Wild & Dicot \\
\hline 17 & Boerhaavia diffusa $\mathrm{L}$. & Nyctaginaceae & Herb & Wild & Dicot \\
\hline 18 & Borassusflabellifer $\mathrm{L}$. & Arecaceae & Tree & Cultivated & Monocot \\
\hline 19 & Calotropis gigantean (L.) & Apocynaceae & Shrub & Wild & Dicot \\
\hline 20 & Cardiospermum halicacabum Linn & Sapindaceae & climber & Wild & Dicot \\
\hline 21 & Cassia auriculata L. & Fabaceae & Shrub & Wild & Dicot \\
\hline 22 & Cassia occidentalis (L.) & Fabaceae & Shrub & Wild & Dicot \\
\hline 23 & Catharanthus pusillus (Murray) G.Don & Apocynaceae & Herb & Wild & Dicot \\
\hline 24 & Celosia argentea L. & Amaranthaceae & Herb & Wild & Dicot \\
\hline 25 & Celosia spicata $\mathrm{L}$. & Amaranthaceae & Herb & Wild & Dicot \\
\hline
\end{tabular}




\begin{tabular}{|c|c|c|c|c|c|}
\hline $\begin{array}{l}\text { Sr. } \\
\text { No }\end{array}$ & Name of the plants & Family & Habit & $\begin{array}{l}\text { Nature of } \\
\text { Plant }\end{array}$ & Cotyledons \\
\hline 26 & Chlorsis barbata (L.) & Poaceae & Herb & Wild & Dicot \\
\hline 27 & Cissus quadarangularis $\mathrm{L}$. & Vitaceae & Shrub & Wild & Dicot \\
\hline 28 & Cleome viscosa $\mathrm{L}$. & Cleomaceae & Herb & Wild & Dicot \\
\hline 29 & Clitoria ternatea L. & Fabaceae & Herb & Wild & Dicot \\
\hline 30 & Cocus nucifera $\mathrm{L}$. & Arecaceae & Tree & Cultivated & Monocot \\
\hline 31 & Corchorus olitorius L. & Malvaceae & Herb & Wild & Dicot \\
\hline 32 & Corchorus trilocularis L. & Malvaceae & Herb & Wild & Dicot \\
\hline 33 & Crotalaria retusa L. & Fabaceae & Herb & Wild & Dicot \\
\hline 34 & Croton sparsiflorus Baill & Euphorbiaceae & Herb & Wild & Dicot \\
\hline 35 & Cyperus odoratus L. & Cyperaceae & Herb & Wild & Dicot \\
\hline 36 & Dactyloctenium aegyptium (L.) willd. & Poaceae & Herb & Wild & Monocot \\
\hline 37 & Daemia extensa (Jacq.) R.Br. Ex schult & Asclepiadaceae & climber & Wild & Monocot \\
\hline 38 & Datura metel $L$. & Solanaceae & Shrub & Wild & Dicot \\
\hline 39 & Delonix regia (Bajex Hook) Raf. & Fabaceae & Tree & Wild & Dicot \\
\hline 40 & Digera muricata (L.) Mart & Amaranthaceae & Herb & Wild & Dicot \\
\hline 41 & Eragrostis tenella (L.) & Poaceae & Herb & Wild & Monocot \\
\hline 42 & Euphorbia antiquorum L. & Euphorbiaceae & Shrub & Wild & Dicot \\
\hline 43 & Euphorbia hirta L. & Euphorbiaceae & Herb & Wild & Dicot \\
\hline 44 & Euphorbia retusa Forssk & Euphorbiaceae & Herb & Wild & Dicot \\
\hline 45 & Euphorbia trigona Mill. & Euphorbiaceae & Shrub & Wild & Dicot \\
\hline 46 & Evolvulus alsinoides (Linn.)Linn. & Convolvulaceae & Herb & Wild & Dicot \\
\hline 47 & Ficus religiosa $\mathrm{L}$. & Moraceae & Tree & Wild & Dicot \\
\hline 48 & Gomphrena celosioides Mart. & Amaranthaceae & Herb & Wild & Dicot \\
\hline 49 & Gomphrena globosa $\mathrm{L}$. & Amaranthaceae & Herb & Wild & Dicot \\
\hline 50 & Gynandra pentaphylla L. & Capparaceae & Herb & Wild & Dicot \\
\hline 51 & Hibiscus rosa-sinensisL. & Malvaceae & Shrub & Cultivated & Dicot \\
\hline 52 & Indigofera linifolia $\mathrm{L}$. & Fabaceae & Herb & Wild & Dicot \\
\hline 53 & Ipomea pestigridis $\mathrm{L}$. & Convolvulaceae & climber & Wild & Dicot \\
\hline 54 & Jatropha curcus L. & Euphorbiaceae & Shrub & Wild & Dicot \\
\hline 55 & Jatropha gossypifolia L. & Euphorbiaceae & Shrub & Wild & Dicot \\
\hline 56 & Justicia adhatoda L. & Acanthaceae & Shrub & Wild & Dicot \\
\hline 57 & Justicia procumbens $\mathrm{L}$. & Acanthaceae & Herb & Wild & Dicot \\
\hline 58 & Justicia simplex D.Don & Acanthaceae & Herb & Wild & Dicot \\
\hline 59 & Kyllinga brevifolia (Rottb.) & Cyperaceae & Herb & Wild & Monocot \\
\hline 60 & Lantana camera L. & Verbenaceae & Shrub & Wild & Dicot \\
\hline 61 & Lawsonia inermis $\mathrm{L}$. & Lythraceae & Shrub & Wild & Dicot \\
\hline 62 & Leucas aspera (willd.) & Lamiaceae & Herb & Wild & Dicot \\
\hline 63 & Melhania incana Heyne ex wight al Arn. & Malvaceae & Herb & Wild & Dicot \\
\hline 64 & Mollugo nudicaulis Lam. & Molluginaceae & Herb & Wild & Dicot \\
\hline 65 & Mollugo pentaphylla & Molluginaceae & Herb & Wild & Dicot \\
\hline 66 & Mukia maderaspatana (L.)M. Roem & Cucurbitaceae & Herb & Wild & Dicot \\
\hline 67 & Ocimum tenuiflorum $L$. & Lamiaceae & Herb & Wild & Dicot \\
\hline 68 & Oldenlandia umbellate $\mathrm{L}$. & Rubiaceae & Herb & Wild & Dicot \\
\hline 69 & Opuntia littoralis Mill. & Cactaceae & Herb & Wild & Dicot \\
\hline 70 & Oxystelma esculentum (L.f.)Sm. & Apocynaceae & climber & Wild & Dicot \\
\hline
\end{tabular}




\begin{tabular}{|c|c|c|c|c|c|}
\hline $\begin{array}{l}\text { Sr. } \\
\text { No }\end{array}$ & Name of the plants & Family & Habit & $\begin{array}{l}\text { Nature of } \\
\text { Plant }\end{array}$ & Cotyledons \\
\hline 71 & Parthenium hysteron Phorus L. & Asteraceae & Herb & Wild & Dicot \\
\hline 72 & Pavonia odorata Cav & Malvaceae & Shrub & Wild & Dicot \\
\hline 73 & Pavonia zeylanica (L.) & Malvaceae & Shrub & Wild & Dicot \\
\hline 74 & Pedalium murex $\mathrm{L}$. & Pedaliaceae & Herb & Wild & Dicot \\
\hline 75 & Peristrophe bicalyculata (Retz.) Nees & Acanthaceae & Herb & Wild & Dicot \\
\hline 76 & Phyllanthus amarus $\mathrm{L}$. & Euphorbiaceae & Herb & Wild & Dicot \\
\hline 77 & Physalis minima $\mathrm{L}$. & Solanaceae & Herb & Wild & Dicot \\
\hline 78 & Plumbago zeylanica $\mathrm{L}$. & Plumbaginaceae & Herb & Wild & Dicot \\
\hline 79 & Pongamia pinnata (L.) & Fabaceae & Tree & Wild & Dicot \\
\hline 80 & Prosopis juliflora (SW) DC. & Fabaceae & Tree & Wild & Dicot \\
\hline 81 & Ricinus communis $\mathrm{L}$. & Euphorbiaceae & Shrub & Wild & Dicot \\
\hline 82 & Saccharum spontaneum $\mathrm{L}$. & Poaceae & Herb & Wild & Monocot \\
\hline 83 & Senna uniflora (Mill.) & Fabaceae & Herb & Wild & Dicot \\
\hline 84 & Setaria barbata (Lam.) Kunth & Poaceae & Herb & Wild & Monocot \\
\hline 85 & Sida acuta Burm.f. & Malvaceae & Herb & Wild & Dicot \\
\hline 86 & Solanum trilobatum L. & Solanaceae & Herb & Wild & Dicot \\
\hline 87 & Spermacoce hispida L. & Rubiaceae & Herb & Wild & Dicot \\
\hline 88 & Stachytarpheta jamaicensis (L.) Vahl & Verbaenaceae & Herb & Wild & Dicot \\
\hline 89 & Tamarindus indica $\mathrm{L}$. & Fabaceae & Tree & Wild & Dicot \\
\hline 90 & Tecoma stans (L.) Juss. Ex kunth & Bignoniaceae & Tree & Wild & Dicot \\
\hline 91 & Tectona grandis L. F & Lamiaceae & Tree & Wild & Dicot \\
\hline 92 & Tephrosia candida Dc. & Fabaceae & Herb & Wild & Dicot \\
\hline 93 & Tephrosia purpurea (L.) Pers. & Fabaceae & Herb & Wild & Dicot \\
\hline 94 & Thespesia populnea (L.) sol. ex correa & Malvaceae & Tree & Wild & Dicot \\
\hline 95 & Thevetia peruviana $\mathrm{L}$. & Apocynaceae & Tree & Wild & Dicot \\
\hline 96 & Trianthema decandra L. MANT. & Aizoaceae & Herb & Wild & Dicot \\
\hline 97 & Trianthema Portulacastrum L. & Aizoaceae & Herb & Wild & Dicot \\
\hline 98 & Tribulus terrestris $\mathrm{L}$. & Zygophyllaceae & Herb & Wild & Dicot \\
\hline 99 & Tridax procumbens $\mathrm{L}$. & Asteraceae & Herb & Wild & Dicot \\
\hline 100 & Triumfetta rhomboidea $\mathrm{L}$. & Malvaceae & Herb & Wild & Dicot \\
\hline 101 & Vernonia cinerea (L.) & Asteraceae & Herb & Wild & Dicot \\
\hline 102 & Xanthium strumarium L. & Asteraceae & Herb & Wild & Dicot \\
\hline 103 & Zea mays $\mathrm{L}$. & Poaceae & Shrub & Cultivated & Monocot \\
\hline
\end{tabular}




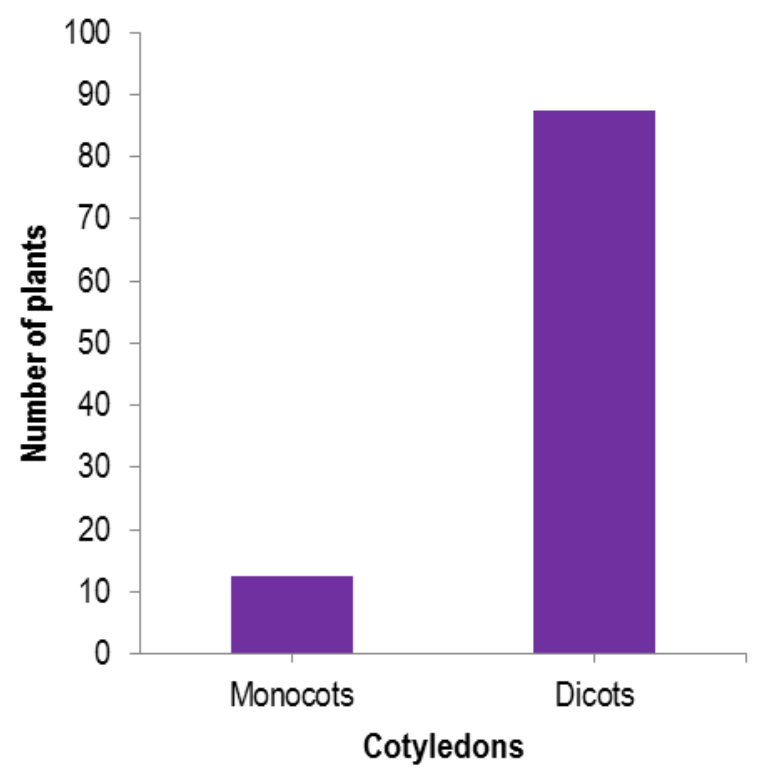

Figure 1 Cotyledon wise distribution of plant species in the study area

Euphorbiaceae is the second largest families with 11 species followed by Malavaceae (10), Amaranthaceae (9), Poaceae (8), Acanthaceae (7), Asterceae (4), Solanaceae (3), Rubiaceae (2), Vitaceae (1) (Table 6, Figure 6) .No endemic species has been found from the study area. The commonly occurring species are Abutilon indicum, Acalpha indica, Barleria sps, Cassia auriculata, Chlorsis barbata, Cocus nucifera, Euphorbia sps, Jatropha curcus, Mollugo nudicaulis, Tamarindus indica, Tribulus terrestris, Tridax prcumbens, Vernonia cinerea. The dominant tree species found are Azadirachta indica, cocus nucifera, Ficus religiosa followed by Tectona grandis (Figure 2). Among the total 103 species, 12 are trees, 22 shrubs, 64 herbs and 5 climbers (Figure 3). More over 96 species are wild and 7 species are cultivated (Figure 4).

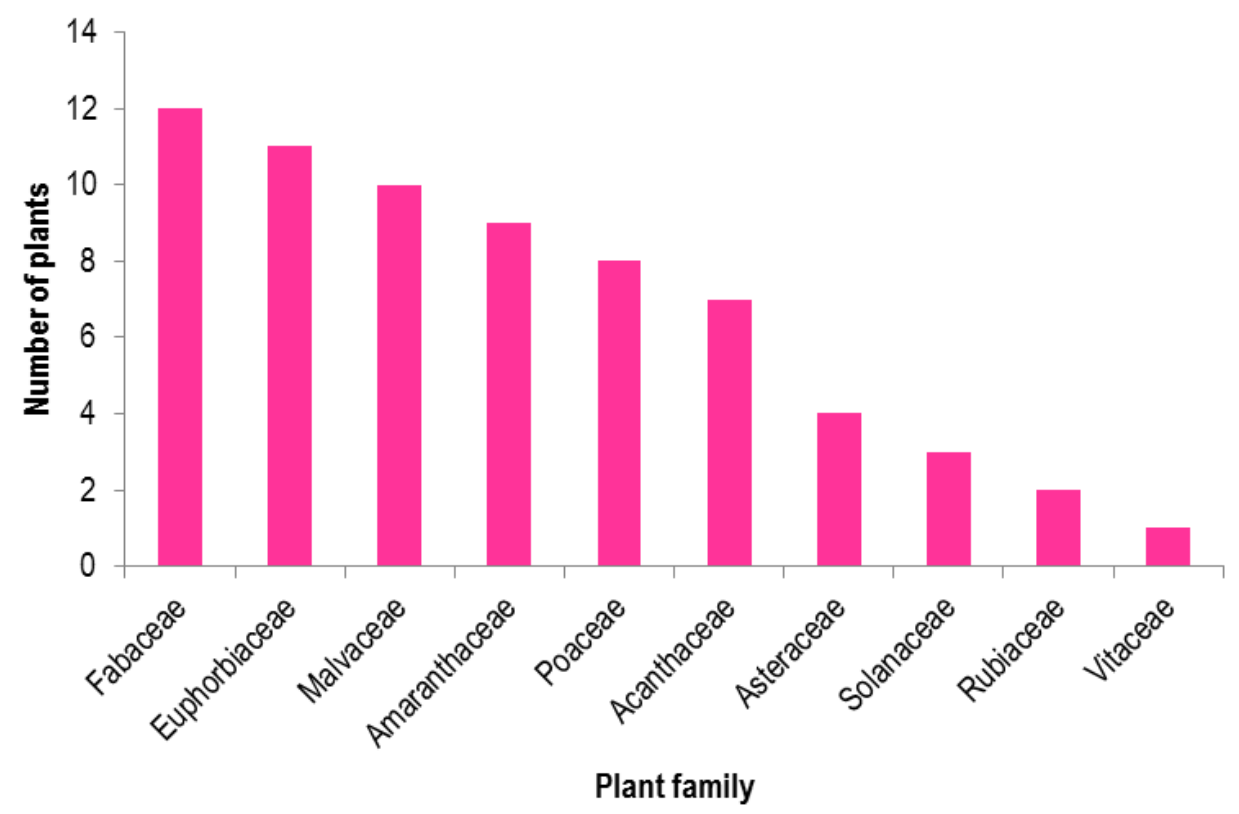

Figure 2 Dominant families observed during the study period 


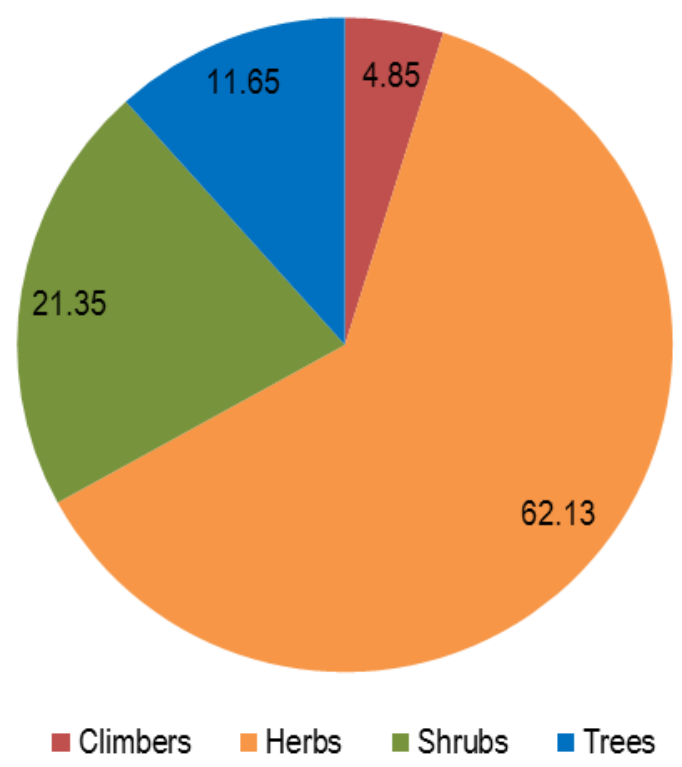

Figure 3 Habit wise distribution of plant species in the study area

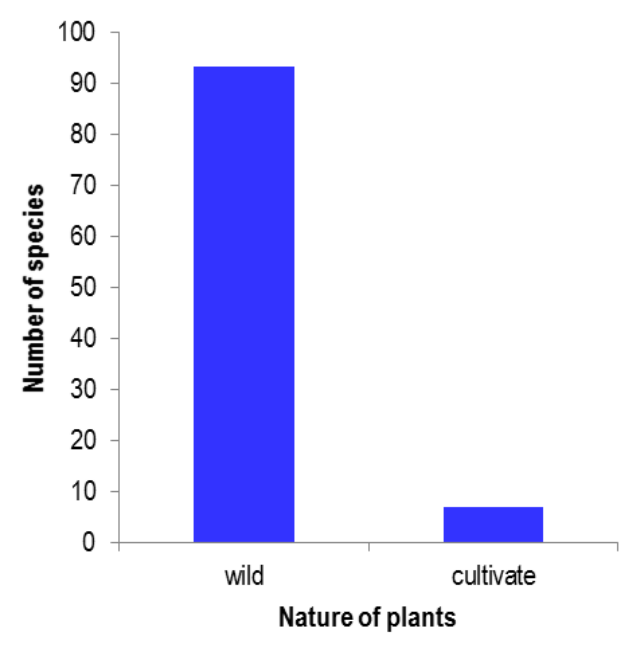

Figure 4 Plant species under Wild/Cultivated ornamental categories

Seeds is used to propagate 103 plant species, 2 species by seeds/stem cutting, 3 species were propagated using their bulbs, 2 species were propagated by stem cutting, Rest of the plants propagated using their different plant parts (bud, corm, Rhizome, seed, tubers) (Figure 5). In this study environmental conditions and propagules maturity etc were found key factors for their regeneration. 


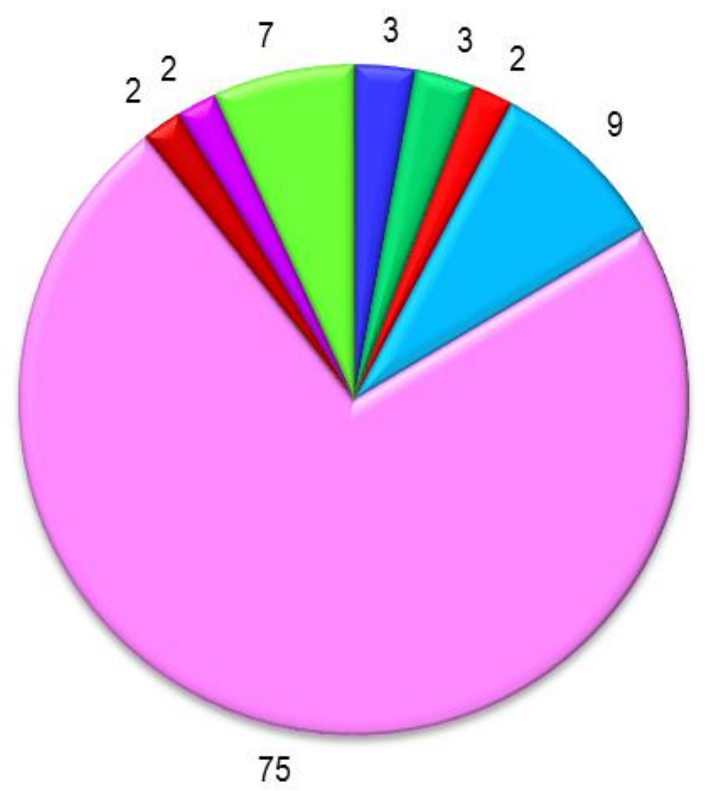

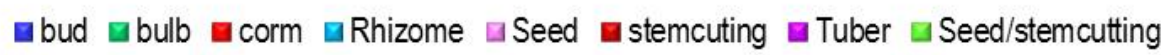

Figure 5 Propagation method of selected plants in the area

Our results indicate that shrubs can be useful to stabilize vegetation and minimize erosion along roadsides and is supported by results from a study on effects of vegetation on runoff from simulations of rainfall showing that grasses and shrubs in combination protected better against runoff and soil detachment rates compared with grasses per se or natural restoration [10]. However, shrubs are disfavored by several natural and human imposed factors, and is anteceded by grasses and forbs in the natural plant succession order. Other functional plant groups, such as graminoids and forbs, tend to spread faster into disturbed areas, as does active management with seeding of graminoids and mowing frequently used to maintain visibility.

In urban areas, biodiversity offers social and biological functions to residents, including ecological balance, ecosystem services, environmental protection, outdoor recreation, aesthetic enjoyment, nature education, and nurturing grounds, shelters, refuges and dispersal centers for wildlife species [11-13]. Roads are man-made urban corridors, an essential part of urban green infrastructure [14]. Roadside trees, as integral part of urban green spaces, are of value to biodiversity, recreation and esthetic [15-17]. They provide home and sustenance for many floral and faunal species. Roadside trees in urban areas have many environmental benefits including removing air pollutants [18-19], improving urban aesthetics and supporting wildlife habitat [20-21], mitigating the "heat island" effect through evapo transpiration and shading sequestering carbon [22], and reducing building energy use for cooling and heating [23].

Roadside trees share similar management concerns and challenges to other urban trees .The specific physical and physiological constraints restrict species selection and affect their management. Usually, the relatively narrow roadside corridor and underground utilities severely confine tree growth in compact city environment. The heavy shading, heat irradiation, pollution, poor soil quality, limited rooting volume and soil compaction would exclude many species from roadside use [24-26]. The need for headroom and lateral clearance for vehicular and pedestrian traffic and adjacent buildings would preclude more species [27]. The high mortality rate of street trees implies that the species with low adaptation to the harsh roadside environment would be eliminated [22]. This in turn would require tree removal and replacement. With increased management cost and reduced funding available, public agency tree managers need tools that will allow them to prolong the service life of public roadside tree populations. The fact that the urban environment is a series of heterogeneous microclimates as Bassuk (1990) stated, the perfect urban tree' that are aesthetically pleasant and can withstand the multitude of environmental stresses encountered by roadside trees does not exist [28]. The differences in environmental variables (drainage, soil fertility, $\mathrm{pH}$, salt and the amount of rooting space) can create so widely differing site conditions that even identical cultivars of street trees possess non-uniform growth. Besides, the lessons of the extensive plantings of a few species in USA proved that this approach is shortsighted [28-29]. Planting monocultures, or extensive plantings relying on only a very few species can create genetic vulnerability by encouraging the build-up of pests and diseases [28]. The cases showed that as most serious pests or problems are specific to certain families, genera, or species of plants, a key to sustainability in urban settings lies not in the selection of any single cultivar 
with a particular set of characteristics but in biological diversity within populations. Having a broad diversity of trees in urban roadsides can guard against the possibility of large-scale devastation by both native and introduced insect and disease pests.

However, for many cities, the danger of monoculture plantings remains real with a very few species making up the greatest percentage of the population [28]. To avoid catastrophic losses and pest outbreaks associated with virtual monocultures, we should maintain a broad diversity of trees. Thus, biodiversity in existing street tree population needed to be assessed.

Species richness on roadside margins as revealed in the current investigations underlines the observations of Tansely, (1949) that roadsides are botanically and ecologically significant places [30]. Moreover, unlike the less diverse and regularly managed roadsides of the west with only few species [31-32], the negligibly managed roadsides of South India showed a rich diversity of resistant species. Apart from some studies on vegetation-site relationship of a broader area [33] and comparison according to climatic differences [34], no specific floristic investigations, especially that of the phytosociological details of resistant species close to tar-edge of roads are mentioned in the literature, even in recent vegetation analyses of roadsides of the Indian subcontinent [35]. Ahmad et al. (2004) [36] reported 227 species from a broad distance of roadsides; but total species diversity so far reported from roadsides close to tar-edgesis less than 70 species [37, 35, 33]. The significant differences in species richness and certain phytosociological characteristics found over urban and rural roadsides occupying same climatic conditions can be attributed to differences in the degree of anthropogenic disturbance over the zones. Non-climatic differences in species richness of roadside vegetations are known earlier [38]. However, the explanations of the differences in vegetation types on urban and rural roadsides without quantitative analytical details of individual species cannot reveal the ecological potentials of different species [39]. Therefore, the inclusion in the present investigation of such details enabled identification of the degree of hypertolerance of very many new species. Phytoremediation is an emerging cost effective eco-technology to deal with heavy metal contaminations and phytomining. These types of plant inventory researches are essential to the preliminary identification of hyper accumulators useful in phytoremediation.

Moreover, many species from the already identified hyper-accumulator plant families such as Poaceae, Asteraceae, Cyperaceae, Fabaceae, Lamiaceae and Euphorbiaceae were found on roadsides in the present studies; the fast growing Poaceae are noted for their tolerance and hyper accumulation capacities [40,41]. The ecological potentials of the dominant grass species noted on these roadsides may be further explored for their specific ecological indications of tolerance or hyper-metal accumulation. The results of this research thus open up new vistas of ecological opportunities, which the exploration of roadside vegetation provides. Disturbance frequently is implicated in the spread of invasive exotic species [42]. Roads being the ecological corridors of exotic species [43], highly disturbed roadsides are open places where natural communities contain many exotic species. If the percentage of exotic species on roadsides is equated to the degree of disturbing environmental influence on the integrity of roadside communities, the South Indian roads with $53 \%$ exotics, ( 45 species), irrespective of seasons or regions, could be assessed as highly disturbed; however, none of the exotics observed were of nationally notified species for control and prevention of spread. Among the total exotics 78\% (35 species) were dicots and only 22\% (10 species) were monocots. The high density and relative abundance of a few monocots over that of many dicots revealed that the former are more invasive on roadsides than the latter. The observation of a sharp and significant increase in the total number of species and also exotics in the urban environment over that of rural zone indicated that the competitions between native and exotic species for establishment in the urban environment are an ongoing and continuous process. It may also be noted that the increase in species richness in the disturbed urban environment cannot be a sign of stability; instead, it appeared that an increase in anthropogenic influence in wet tropical urban system of developing countries can be associated with an increase in the number of exotics in general, which contributes to a general increase in species diversity in such places. Euphorbia indica, a well-known exotic roadside invader species [44, 45] and Cynodon dactylon, a cosmopolitan dominant roadside tolerant species [46] were observed on these roadsides also, in plenty. The overall assessment is that contaminated roadsides botanical expeditions to find out hyper-resilient species against physico-chemical disturbance, which are ecologically significant in many ways. Such inventories of plants in relation to their environmental characteristics can be suggested as the task of botanists and ecologists towards the preliminary identification of hyper accumulators, which are essential to the fast emerging of eco-technologies such as phytoremediation. Systematic phytosociological analyses of vegetations are inevitable to such investigatory expeditions. This suggests roadside verges may play an important role in conserving Cerrado biodiversity, as a stepping stone for isolated animal populations, and as a reservoir of plant genetic diversity. In the light of the focus on roads as a conduit for plant invasions, it is perhaps not unexpected that so little is known regarding the traits of species that manage to persist in roadside habitats [47-48]. Thick bark enhances survivorship of plants exposed to fire [49-50], which is probably the mechanism underlying why plots on roadsides had fewer plants with thin bark than those in reserves. Frequent fires may also be why species and individuals typical of savanna formations were significantly more prevalent in the reserves than in roadsides. 


\section{Conclusion}

Roads play a pivotal part in the infrastructure of countries; however, their construction can lead to detrimental effects on the surrounding environment, with local ecosystems being heavily affected. Therefore, as engineers, it is our role to try and minimize these harmful consequences of road building and if possible, eradicate these factors all together. It may even be possible to improve some aspects of the surrounding ecosystems through thorough planning of biodiversity-neutral roads and the implementation of road runoff collection and treatment systems. The present study is a strong first step and warrants further effort, which may pave the way to screen the feasibility of these plants in context of their potentiality to be planted in other urban areas with varying pollution load. In a nutshell, the use of urban roadside plants as bio indicators or biomarkers is an inexpensive and convenient technique and thus offers an ecosustainable green tool for urban ecosystem restoration.

\section{Compliance with ethical standards}

\section{Acknowledgments}

The authors are thankful to Department of Botany, S. T. Hindu College for providing necessary facilities for carrying out the work.

\section{Disclosure of conflict of interest}

We declare that we have no conflict of interest.

\section{References}

[1] Zeng S, Zhang T, Gao Y, Ouyang Z, Chen J, Li B and Zhao B. (2010). Effects of road disturbance on plant biodiversity. World Academy of Science, Engineering and Technology, 66, 437-448.

[2] Ullman L, Bannister P and Wilson JB. (1995). The vegetation of roadside verges with respect to environmental gradients in southern New Zealand. Journal of Vegetation Science, 6, 131-142.

[3] Delgaodo JD, Arrolo NL, Fernandez - palacios JM. (2007). Edge effects of roads on temperature, light, canopy cover and canopy height in laural and pine forests. Landscape and Urban Planning, 81, 328-340.

[4] Pauchard A and Alaback PB. (2006). Edge type defines alien plant species invasions along Pinus contorta burned, highway and clear cut forest edges. Forest Ecology and Management, 223, 327-335.

[5] Gamble JS and Fischer CEC. (1967). Flora of the presidency of Madras, Reprint Edition, Botanical Survey of India, Calcutta.

[6] Nair NC and Henry AN. (1983). Flora of Tamil Nadu, India. Series 1: Analysis. Volume 1, Botanical Survey of India, Coimbatore, 184.

[7] Henry AN, Kurmai GR and Chitra V. (1987). Flora of Tamil Nadu, India. Series I: Analysis. Volume 2, Botanical Survey of India, Coimbatore, 285.

[8] Henry AN, Chitra V and Balakrishnan NP. (1989). Flora of Tamil Nadu, India.Series I: Analysis. Volume 3, Botanical Survey of India, Coimbatore, 171.

[9] Jain SK and Rao PR. (1977). Handbook of field and herbarium methods. Scholarly Publications, New Delhi.

[10] Liu YJ, Wang TW, Cai CF, Li, ZX and Cheng DB. (2014). Effects of vegetation on runoff generation, sediment yield and soil shear strength on road-side slopes under a simulation rainfall test in the three gorges reservoir area, China. Science of the Total Environment, 485, 93-102.

[11] Box J and Harrison C. (1994). Minimum targets for accessible natural green space in urban areas. Urban Wildlife News, 11, 10-11.

[12] Cilliers SS, Müller N and Drewes E. (2004). Overview on urban nature conservation: situation in the westerngrassland biome of South Africa. Urban Forestry and Urban Greening, 3, 49-62.

[13] Reduron JP. (1996). The role of biodiversity in urban areas and the role of cities in biodiversity conservation. In Di Castri F and Younes T (Eds), Biodiversity, science and development: Towards a new partnership. CAB International, Wallingford, 551-557. 
[14] Ranta P, Kesulahti J, Tanskanen A, Viljanen V and Virtanen T. (2015). Roadside and riverside green - urban corridors in the city of Vantaa, Finland. Urban Ecosystem, 18, 341-354.

[15] Bernath K and Roschewitz A. (2008). Recreational benefits of urban forests: explaining visitors' willingness to pay in the context of the theory of planned behavior. Journal of Environmental Management, 89, 155-166.

[16] Rowntree R. (1984). Ecology of the urban forest - introduction to part I. Urban Ecology, 8, 1-11.

[17] Tyrvainen L, Pauleit S, Seeland K and De Vries S. (2005). Benefits and uses of urban forests and trees. In: Konijnendijk C, Nilsson K, Randrup T, Schipperijn, J (Eds), Urban Forests and Trees. Springer, Verlag Berlin Heidelberg, 81-114.

[18] Kiran SG and Kinnary S. (2011). Carbon sequestration by urban trees on roadsides of Vadodara city. International Journal of Engineering Science and Technology, 3(4), 3666-3070.

[19] McPherson EG, Nowak D, Heisler G, Grimmond S, Souch C, Grant R and Rowntree R. (1997). Quantifying urban forest structure, function, and value: the Chicago Urban Forest Climate Project. Urban ecosystems, 1(1), 49-61.

[20] Clark JR, Matheny NE, Cross G and Wake V. (1997). A model of urban forest sustainability. Journal of Arboriculture, 23, 17-30.

[21] Schwaab EC, Alban L, Riley J, Rabaglia R and Miller KE. (1995). Maryland's forests: A health report. Maryland Department of Natural Resources-Forest Service, Annapolis, MD, 48.

[22] McPherson GE, Nowak DJ and Rowntree RA. (1994). Chicago's urban forest ecosystem: results of the Chicago Urban Forest Climate Project. Gen. Tech. Rep. NE-186. Radnor, PA: US Department of Agriculture, Forest Service, Northeastern Forest Experiment Station. 201 p, 186.

[23] Akbari H, Davis S, Dorsano S, Huang J and Winnett S. (1992). Cooling our communities: A guidebook on tree planting and light-colored surfacing. Government Printing Office, Washington, DC, 217.

[24] Bassuk N and Whitlow T. (1987). Environmental stress in street trees. Acta Horticulturae, 195, 49-57.

[25] Buhler 0, Kristoffersen P and Larsen SU. (2007). Growth of street trees in Copenhagen with emphasis on the effect of different establishment concepts. Arboriculture and Urban Forestry, 33, 330-337.

[26] Jim CY. (1999). A planning strategy to augment the diversity and biomass of roadside trees in urban Hong. Landscape and Urban Planning, 44(1), 13-32.

[27] Galvin MF. (1999). A methodology for assessing and managing biodiversity in street tree populations: a case study. Journal of Arboriculture, 25, 124-128.

[28] Bassuk NL. (1990). Street tree diversity making better choices for the urban landscape. Metria Proceedings, 7178.

[29] Nannini, DK, Sommer R and Meyers LS. (1998). Resident involvement in inspecting trees for Dutch Eem disease. Journal of Arboriculture, 24, 42-46.

[30] Tansely AG. (1949). The British Islands and their vegetation. Cambridge University Press, Cambridge.

[31] Way JM. (1977). Roadside verges and conservation in Britain: a review. Biological Conservation, 12, $65-74$.

[32] Ross SM. (1986). Vegetation change on highway verges in South-east Scotland. Journal of Biogeography, 13, 109117.

[33] Rentch JS, Fortney RH, Stephenson SL, Adams HS, Grafton WN and Anderson JT. (2005). Vegetation- site relationships of roadside plant communities in West Virginia, USA. Journal of Applied Ecology, 42, $129-138$.

[34] Ullmann I, Bannister P and Wilson JB. (1995). The vegetation of roadside verges with respect to environmental gradients in southern New Zealand. Journal of Vegetation Science, 6(1), 131-142.

[35] Akbar KF, Ahmad Z, Shad MA and Ansari TM. (2003). An Ecological study of roadside vegetation and soils in Sahiwal district. Online Journal of Biological Sciences, 3(7), 627-634.

[36] Ahmad SS, Ahmad T and Akbar KF. (2004). Baseline study of roadside vegetation of Lahore-Islamabad motorway (M-2) and its fertility status. Journal of Applied Sciences, 4(20), 266-270.

[37] Wester L and Juvik JO. (1983). Roadside plant communities on Mauna Loa, Hawaii. Journal of Biogeography, 10, 307-316. 
[38] Wilson JB, Gillian LR, Martin TS, Anni JW and Williams PA. (1992). Distributions and climatic correlations of some exotic species along roadside in South Island, New Zealand. Journal of Biogeography, 19, 183-194.

[39] Cilliers SS and Bredenkamp GJ. (2000). Vegetation on road verges on an urbanization gradient in Potchefstroom, South Africa. Landscape and Urban Planning, 46(4), 217-239.

[40] Prasad MNV. (2005). Nickelophilous plants and their significance in phytotechnologies. Brazilian Journal of Plant Physiology, 17(1), 113-128.

[41] Jankaite A and Vasarevicius S. (2007). Use of Poaceae f. species to decontaminate soil from heavy metals. Ekologija, 53 (4), 84-89.

[42] Larson DL. (2003). Native weeds and exotic plants relationship to disturbance in mixed - grass prairie. Plant Ecology, 169, 317 - 333 .

[43] Trombulak SC and Frissell CA. (2000). Review of ecological effects of roads on terrestrial and aquatic communities. Conservation biology, 14 (1), 18-30.

[44] Anoliefo GO, Ikhajiagbe B, Okonofhua BO and Diafe FV. (2005). Eco- Taxonomic distribution of plant species around motor mechanic workshops in Asaba and Benin City Nigeria: Identification of oil tolerant plant species. African Journal of Biotechnology, 4(19), 1757-1762.

[45] Goosem M. (2006). Weed surveys along highways, roads and powerline clearings traversing the Wet Tropics World Heritage Area. Weed incursions along roads and powerlines in the Wet Tropics World Heritage Area: The potential of remote sensing as an indicator of weed infestations (2006), 1-25.

[46] Taranath TC, Ratageri RH, Mulgund GS and Giriyappanavar BS. (2005). Cynodon dactylon - A phytotool to monitor heavy metal pollution in roadside environment. Nature Environment and Pollution Technology, 4 (3), $367-371$.

[47] Parendes LA and Jones JA. (2000). Role of light availability and dispersal mechanisms in invasion of exotic plants roads and streams in the HJ Andrews Experimental Forest, Oregon. Conservation Biology, 14, 64-75.

[48] Zeng SL, Zhang TT, Gao Y, Ouyang ZT, Chen JK, Li B and Zhao B. (2011). Effects of road age and distance on plant biodiversity: a case study in the Yellow River Delta of China. Plant Ecology, 212(7), 1213-1229.

[49] Uhl C and Kauffman JB. (1990). Deforestation, fire susceptibility, and potential tree responses to fire in the eastern Amazon. Ecology 71, 436-449.

[50] Hengst GE and Dawson JO. (1993). Bark properties and fire resistance of selected tree species from the central hardwood region of North America. Canadian Journal of Forest Research, 24, 688-696.

\section{How to cite this article}

Kensa MV, Sangeetha M and Lekshmi JL. (2018). Road side flora of Pazhavoor, Tirunelveli district, Tamil Nadu, South India. GSC Biological and Pharmaceutical Sciences, 4(1), 53-63. 